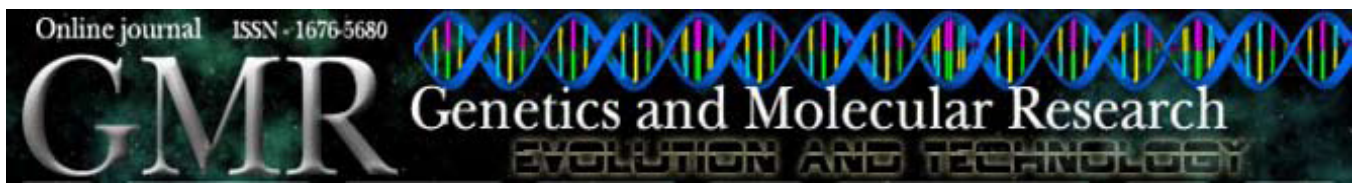

\title{
Pollen foraging in colonies of Melipona bicolor (Apidae, Meliponini): effects of season, colony size and queen number
}

\author{
S.D. Hilário ${ }^{1}$ and V.L. Imperatriz-Fonseca ${ }^{2}$ \\ ${ }^{1}$ Departamento de Zoologia, Instituto de Biociências, \\ Universidade de São Paulo, São Paulo, SP, Brasil \\ ${ }^{2}$ Departamento de Biologia, Faculdade de Filosofia, \\ Ciências e Letras de Ribeirão Preto, \\ Universidade de São Paulo, Ribeirão Preto, SP, Brasil \\ Corresponding author: S.D. Hilário \\ E-mail: sedilar@usp.br
}

Genet. Mol. Res. 8 (2): 664-671 (2009)

Received December 12, 2008

Accepted January 26, 2009

Published June 9, 2009

\begin{abstract}
We evaluated the ratio between the number of pollen foragers and the total number of bees entering colonies of Melipona bicolor, a facultative polygynous species of stingless bees. The variables considered in our analysis were: seasonality, colony size and the number of physogastric queens in each colony. The pollen forager ratios varied significantly between seasons; the ratio was higher in winter than in summer. However, colony size and number of queens per colony had no significant effect. We conclude that seasonal differences in pollen harvest are related to the production of sexuals and to the number of individuals and their body size.
\end{abstract}

Key words: Melipona bicolor; Stingless bees; Pollen foragers; Colony size; Queen numbers; Seasonality 


\section{INTRODUCTION}

Pollen, the main protein source for larvae and adult bees, is one of the principal resources gathered by bees; its use is highly related to brood production (Roubik, 1989; Roulston and Cane, 2000; Thorp, 2000). In social Apidae, foragers carry pollen to their nests on their hind tibial corbiculae (Thorp, 2000). Pollen can be stored in the nests, for future use when climatic conditions become unfavorable for foraging (Roubik, 1982, 1989; Lacerda et al., 1991). Bees and their colonies have to fit their pollen needs to the availability of flowering plant species, which varies seasonally (Fowler, 1979; Roubik, 1982; Eltz et al., 2001; Ramalho, 2004).

Intra-colonial factors can also influence the foraging behavior of the bees (Roubik, 1989; Hilário et al., 2000, 2003; Biesmeijer and Slaa, 2004; Hofstede and Sommeijer, 2006). Pollen storage and pollen harvesting are related to colony size (number of individuals) and worker behavior, since larger colonies have more individuals and foragers than smaller ones (Roubik, 1982).

We investigated the ratio between the number of pollen foragers and the total number of bees entering the colony in a eusocial stingless bee, Melipona bicolor bicolor. Variables considered in our analysis were: season, colony size and number of physogastric queens in each colony.

\section{MATERIAL AND METHODS}

Melipona bicolor (Lepeletier, 1836) is unique among the stingless bees because of its facultative polygyny, which is rare among eusocial bees (for a review, see Velthuis et al., 2006). It is an inhabitant of Atlantic Rainforest and Araucaria Forest, where it nests in hollows of live and dead trees. This bee species is found from South to East Brazil, Bahia State, Paraguay and Argentina (Camargo and Pedro, 2008).

Twenty colonies of Melipona bicolor bicolor Lepeletier from Cunha, São Paulo State $\left(23^{\circ} 05^{\prime} \mathrm{S}, 44^{\circ} 55^{\prime} \mathrm{W}\right)$ were kept in wooden boxes measuring $33(\mathrm{~L}) \times 25(\mathrm{~W}) \times 12(\mathrm{H}) \mathrm{cm}$ at the Bee Laboratory of the Ecology Department, University of São Paulo in the city of São

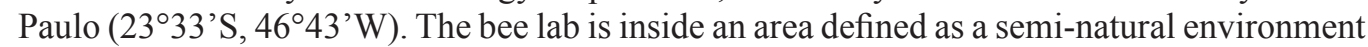
(Wilms and Wiechers, 1997). The local climate is Cfb (Köppen), i.e., constantly moist with rain throughout the year, with fresh winters and hot summers (Herrera et al., 1997).

The colonies were categorized as large, small or medium according to the general conditions, as estimated by number of bees, brood comb size and number of food pots (see Hilário et al., 2000); the number of physogastric queens present in each colony was also noted. These colonies will be referred hereafter as M1 to M20.

A total of 1700 observations were made, 855 in winter and 845 in summer. The winter observations were made from 8:00 to 18:00 h, from July 26 to September 10, 1993 (colonies M1 to M7) and from August 8 to September 5, 1995 (colonies M8 to M10). The summer observations were made from 6:00 to 19:00 h, from February 11 to 15, 2002 (colonies M11 to M17) and from March 1 to 8, 2006 (colonies M18 to M20). Each observation lasted 5 min and involved counting of the total number of bees that entered the colony, carrying or not visibly apparent material. The number of pollen foragers was also noted. Air temperature and relative humidity were also recorded before each count, with a thermo-hygrometer.

We calculated for each colony the ratio between the number of pollen foragers and the total number of bees entering the colony, just as Moretto et al. (1990) did. All ratios were reported as percentages. Henceforth these ratios will be called "P:E values". For statistical 
analysis the SPSS for Windows release 8. 0. was used. The Kruskal-Wallis test was used for differences in P:E values between seasons, colony size and number of physogastric queens. Spearman correlations were also made between P:E values, colony size and number of physogastric queens within each season.

Numerical data from other authors were rarely available for comparison (Table 1). The Image Tool for Windows, version 3.0, developed by researchers from the University of Texas Health Science Center in San Antonio was used to measure the number of pollen foragers and the total number of bees entering the colony, based on the figures published in these papers.

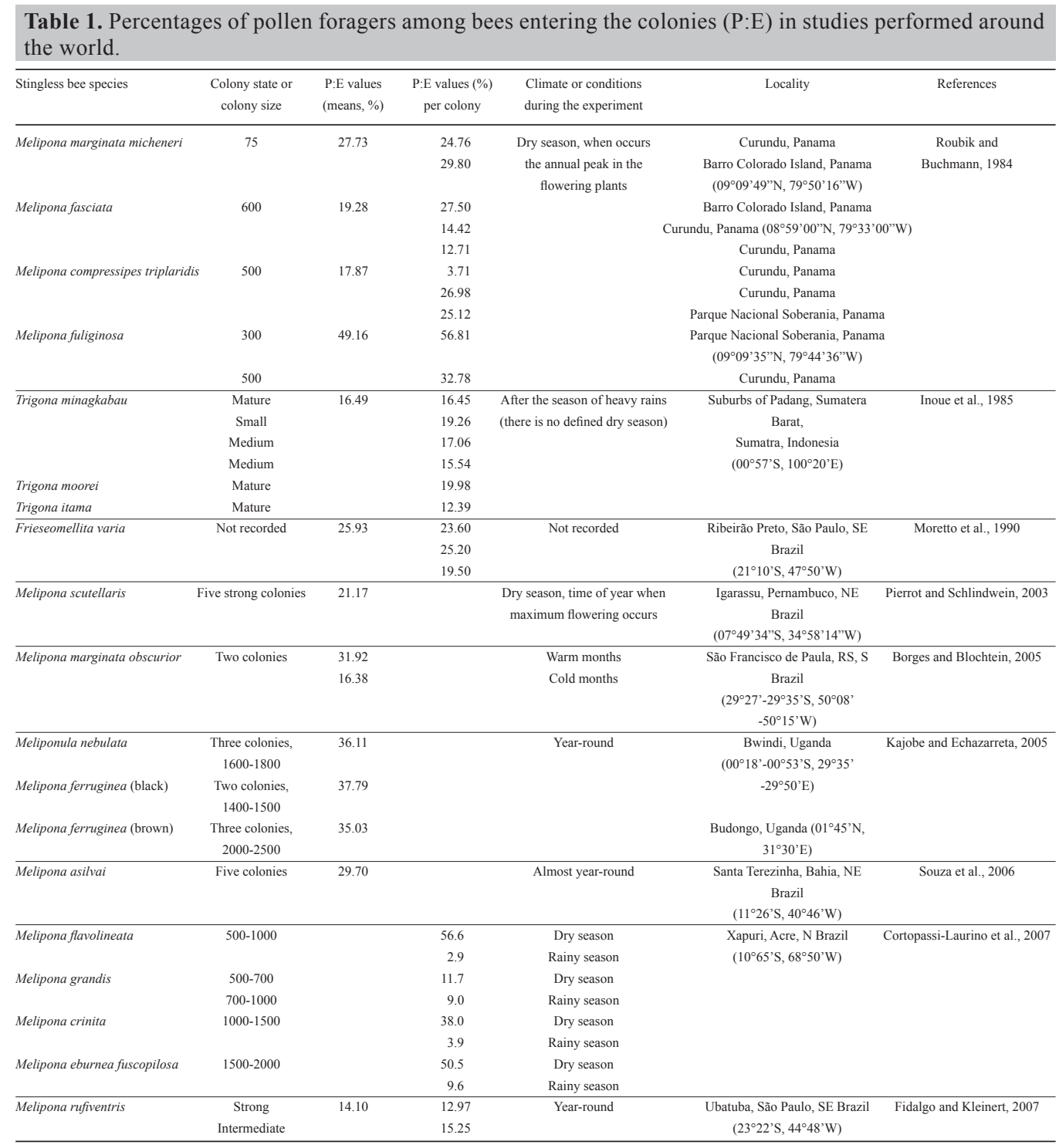




\section{RESULTS}

Air temperatures (mean $\pm \mathrm{SD}$ ) measured at the study site during the experiment in winter were: $18.9 \pm 3.6^{\circ} \mathrm{C}(1993), 22.5 \pm 4.2^{\circ} \mathrm{C}(1995)$, and in summer: $24.5 \pm 3.4^{\circ} \mathrm{C}(2002)$, $25.6 \pm 3.4^{\circ} \mathrm{C}$ (2006). Relative humidity (mean \pm SD) was: $77.8 \pm 11.7 \%$ (1993) and $57.5 \pm$ $14.9 \%$ (1995) in winter, and $76.9 \pm 17.3 \%$ (2002) and $74.8 \pm 23.1 \%$ (2006) in summer.

The mean P:E value in M. bicolor was 15.54\%, ranging from 2.63 (M11) to $39.10 \%$ (M1). In general, P:E values in winter (mean $=23.76 \%)$ were higher than those in summer (mean $=9.02 \%$ ), showing that there were more pollen foragers in winter than in summer (Figure 1).

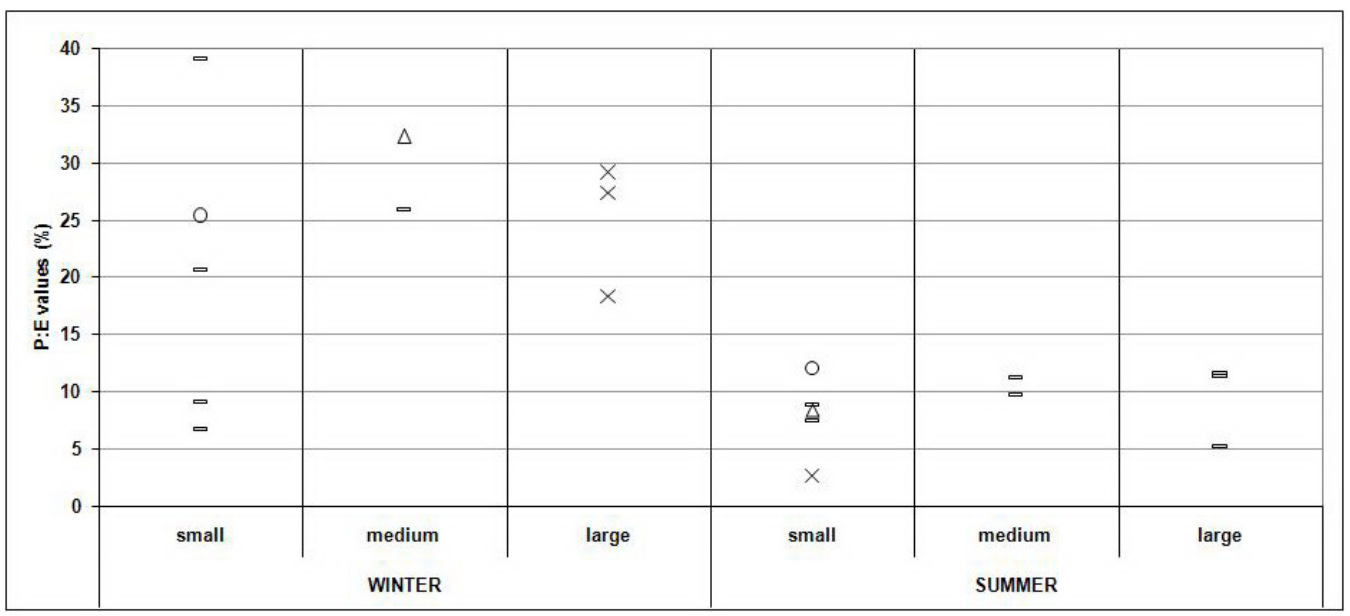

Figure 1. Percentage of pollen foragers among bees entering the small, medium and large colonies of Melipona bicolor, without a queen (circle), with one queen (bar), with two queens (cross), or three queens (triangle), in winter and summer.

The P:E values differed significantly between summer and winter $(\mathrm{H}=7.823$; d.f. $=$ $1 ; \mathrm{P}=0.005)$, but were not affected by colony size $(\mathrm{H}=1.945$; d.f. $=2 ; \mathrm{P}=0.378)$ or by the number of physogastric queens present in each colony $(\mathrm{H}=1.602$; d.f. $=3 ; \mathrm{P}=0.659)$. An association was found between the $\mathrm{P}: \mathrm{E}$ values and seasons of the year ( $\mathrm{rho}=-0.642 ; \mathrm{P}=0.002$ ). During winter, there was a significant correlation between colony size and the number of physogastric queens ( $($ ho $=0.790 ; \mathrm{P}=0.007$ ), but not during summer ( $\mathrm{rho}=-0.202 ; \mathrm{P}=0.575$ ).

The P:E value means classified by colony size in winter were: 24.29 (small), 28.04 (medium) and 22.71 (large). In summer, the values were: 6.21, 10.45 and 9.03, respectively. The P:E values were not correlated with colony size (winter: rho $=0.303 ; \mathrm{P}=0.395$; summer: rho $=0.289 ; \mathrm{P}=0.417$ ) or with the number of physogastric queens in each colony in winter $(r h o=0.374 ; P=0.287)$. But in summer, a significant correlation was found between $P: E$ values and the number of physogastric queens ( $\mathrm{rho}=-0.649 ; \mathrm{P}=0.042$ ).

Generally, P:E values were not related to colony size or to the number of physogastric queens in each colony (Figure 1). 


\section{DISCUSSION}

The flight activity of bees and pollen release by plants are both influenced by environmental factors (Roubik, 1989). Although tropical seasonality is not as well defined in the Southern Hemisphere as in Northern Hemisphere, seasons might play a role in the foraging behavior of bees in subtropical areas (Fowler, 1979). The climatic conditions in our study area were not similar to those recorded historically (1961-1990), due to warm winters and summers (Climanálise, 2002, 2006). Nevertheless, summer temperatures were higher than winter ones and, as expected, in absolute terms, the number of foraging flights was higher in summer than in winter. This number was also higher in large colonies than in small ones. In some cases, our P:E values were similar to those found in other studies (Table 1). For example, the general mean for M. bicolor was similar to the mean of M. rufiventris (in a one-year study), as also some P:E values in winter (Figure 1) were similar to those of several other Melipona species (Table 1). However, the differences in temperature and floral resource availability, as well as in the physiology and behavior of the stingless bees, make a more detailed comparison difficult, even with respect to seasonality. Nevertheless, there appears to be an influence of flora on P:E values (Table 1) when we compare the values obtained at Curundu with those from Barro Colorado Island or from Parque Nacional Soberania (Roubik and Buchmann, 1984). In our study area, winter is a cold and dry season, and flowering increases considerably in spring, a quite different condition from that found in Panama (Roubik and Buchmann, 1984), in Indonesia (Inoue et al., 1985), in Uganda (Kajobe and Echazarreta, 2005) or in the Brazilian Amazon (Cortopassi-Laurino et al., 2007).

However, percentages of pollen foragers that entered the colonies were higher in winter than in summer. As these data were obtained after a hiatus of at least seven years, changes in the local flora could have affected pollen availability. Although polylectic, M. bicolor foragers prefer pollen from Myrtaceae, Melastomataceae and Solanaceae (Ramalho et al., 1989; Wilms and Wiechers, 1997). These plant families have been in our study area since at least the 70's (Iwama and Melhem, 1979; Rensi, 2006). Therefore, we consider that this hiatus did not influence our results.

Another factor that could have influenced the seasonal differences in P:E values of $M . b i$ color would be the arrival of new colonies of diverse species of stingless bees in the laboratory, after 1996. Competition could have resulted in the harvest of a smaller amount of pollen by the bees during the summers of 2002 and 2006 compared to the winters of 1993 and 1995. An example of possible competition was observed in the daily P:E values of Trigona itama; during the two first days of the study of Inoue et al. (1985) they were higher (25.62\%) than those of Trigona minangkabau (14.69\%) and Trigona moorei (18.53\%). During the other two days, P:E values of these species were higher (T. minangkabau: $18.18 \%$; T. moorei: $22.09 \%)$ than the ones of T. itama $(3.7 \%$; the values of Table 1 refer to the complete period of the study, i.e, 4 days).

Fortunately, we could investigate the seasonality in P:E values of studies performed with another species in the same study area, in the same year or in subsequent years. In 1994, P:E values for one colony of Plebeia pugnax Moure (in litt.) were higher in summer (21.0\%) than in winter (15.1\%) (Hilário and Imperatriz-Fonseca, 2002). Sanches (2002) observed that in 5 of 6 colonies de Friesella schrottkyi, P:E values were higher in cold (32.5, 43.0, 42.7, $48.7,42.5$, and $30.6 \%)$ than in warm months $(27.3,20.0,35.1,44.1,37.0$, and $44.5 \%)$. Rensi (2006) mentioned that P:E values in two colonies of Melipona marginata were higher in winter $(2004 ; 3.3$ and $4.5 \%)$ than in summer (2003-2004; 2.1 and 3.1\%). Nunes-Silva (2007) 
found that P:E values in two colonies of Plebeia remota were higher during the phase of queen oviposition (summer of 2006-2007; 29.7 and 24.8\%) than in the reproductive diapause phase (cold months, 2006; 2.2 and 3.7\%).

Thus, with respect to seasonality, our results were similar to those obtained by Sanches (2002) and Rensi (2006), but were different from those reported by Hilário and ImperatrizFonseca (2002) and Nunes-Silva (2007). However, the species in these studies were small bees that adopt different strategies for low-cost survival, as for instance, reproductive diapause in $P$. remota during cold months (see Ribeiro et al., 2003, for more details). The differences between the P:E values of M. marginata at our study site (Rensi, 2006) and in Rio Grande do Sul State (Table 1; Borges and Blochtein, 2005) could be related to the phenomenon of reproductive diapause occurring only in the latter species. Nunes-Silva (2007) suggests that reproductive diapause might be an important intra-colonial factor influencing foraging behavior during winter. Generally, species that do not present diapause collect more pollen in winter than in summer and species that go into diapause do the opposite.

Other factors can affect P:E values. In 2002, the external entrance of a large colony (M14) was removed one week before the experiment. Since it had stored pollen, there were few pollen foragers $(5.26 \%)$ as the bees collected copious amounts of mud to rebuild their entrance. In 2006, a few days before the experiment, two colonies (M18 and M20) had a significant loss in population (including the only physogastric queen: M20). Certainly, this influenced pollen harvesting by the bees (M18: 8.33\%; M20: 12.00\%). Similarly, foragers from one colony of Melipona compressipes triplaridis concentrated their efforts almost solely on nectar collection, while workers from a colony of Melipona fuliginosa harvested much more pollen than nectar (Table 1; Roubik and Buchmann, 1984). Sudden mass flowering events ("big bang" flowering) may also affect harvesting behavior (Nagamitsu and Inoue, 2002; Ramalho, 2004). An illustrative example of this phenomenon was observed by Pierrot and Schlindwein (2003) in Melipona scutellaris. The mean P:E value for November and December was $13.16 \%$; it increased to $37.15 \%$ when there was "big bang" flowering. Consequently, we can see that the internal needs of the colonies (intra-colonial factors) drive their harvesting behavior (Roubik, 1989; Hilário et al., 2000, 2003; Biesmeijer and Slaa, 2004; Hofstede and Sommeijer, 2006).

We evaluated the pollen influx, but did not look at the size or quality of this pollen. Pollen quality is mainly measured by the protein content, which determines the growth of the larvae and consequently, the body size of the bees (Roulston and Cane, 2000). Pollen harvesting is affected by forager and colony size. Smaller foragers carry relatively more pollen than bigger ones in the same species (Ramalho et al., 1998). On the other hand, bigger colonies produce larger foragers (Lacerda et al., 1991; Ramalho et al., 1998; Hilário et al., 2003) and have more individuals (and foragers) than smaller ones (Hilário et al., 2000). Thus, bigger colonies harvest larger quantities of pollen than intermediate and smaller colonies.

We suggest that the small percentage of pollen foragers in summer affects the larval food of bees that will be born in autumn and winter. During cold months, the number of bees is in decline, but they have a large body mass and greater longevity (van Benthem et al., 1995; NunesSilva, 2007). On the other hand, the higher percentage of pollen collectors in the winter reflects in an increased number of bees in the spring and summer, with small body mass and shorter longevity. This is at a time when there is an abundance of floral resources to be harvested.

An alternative (or additive) explanation is based on sex determination in Melipona, which is genetic, although food can maximize the queen production in the colonies (Kerr et al., 
1966). Thus, the pollen harvested in excess during winter can be employed in the elaboration of more larval food, allowing the colonies to invest in the production of gynes. This would help explain why Alves and Imperatriz-Fonseca (2004) observed a large production of gynes in Melipona bicolor colonies in spring and summer.

\section{ACKNOWLEDGMENTS}

We are indebted to Dr. Marilda Cortopassi-Laurino, Dr. Márcia de Fátima Ribeiro, M.Sc. Patricia Nunes-Silva, and the Ph.D. student Denise de Araujo Alves, who contributed to the improvement of this paper. S.D. Hilário expresses his gratitude for the financial support provided by CNPq (\#140169/2000) and FAPESP (04/15801-0). This paper is dedicated to Dr. Warwick Estevam Kerr and his valuable contribution to our knowledge about bees.

\section{REFERENCES}

Alves DA and Imperatriz-Fonseca VL (2004). Production of Gynes, Males and Workers in Melipona bicolor Lepeletier, 1836 (Apidae, Meliponini). Universidade de São Paulo, Ribeirão Preto, 754.

Biesmeijer JC and Slaa EJ (2004). Information flow and organization of stingless bee foraging. Apidologie 35: 143-157.

Borges F Von B and Blochtein B (2005). Atividades externas de Melipona marginata obscurior Moure (Hymenoptera, Apidae), em distintas épocas do ano, em São Francisco de Paula, Rio Grande do Sul, Brasil. Rev. Bras. Zool. 22: 680-686.

Camargo JMF and Pedro SRM (2008). Meliponini Lepeletier, 1836. In: Catalogue of Bees (Hymenoptera, Apoidea) in the Neotropical Region (Moure JS, Urban D and Melo GAR, eds.). Available at [http://www.moure.cria.org.br/ catalogue]. Accessed January 26, 2009.

Climanálise (2002). Boletim de Monitoramento e Análise Climática. Vol. 17, No. 02, 2002. Cachoeira Paulista, SP, Brazil. Available at [http://www.cptec.inpe.br/products/climanalise]. Accessed June 29, 2007.

Climanálise (2006). Boletim de Monitoramento e Análise Climática. Vol. 21, No. 03, 2006. Cachoeira Paulista, SP, Brazil. Available at [http://www.cptec.inpe.br/products/climanalise]. Accessed June 29, 2007.

Cortopassi-Laurino M, Velthuis HHW and Nogueira-Neto P (2007). Diversity of stingless bees from the Amazon forest in Xapuri (Acre), Brazil. Proc. Exp. Appl. Entomol. 18: 105-114.

Eltz T, Brühl CA, Van der Kaars S, Chey VK, et al. (2001). Pollen foraging and resource partitioning of stingless bees in relation to flowering dynamics in a southeast Asian tropical rainforest. Insectes Soc. 48: 273-279.

Fidalgo AO and Kleinert AM (2007). Foraging behavior of Melipona rufiventris Lepeletier (Apinae; Meliponini) in Ubatuba, SP, Brazil. Braz. J. Biol. 67: 133-140.

Fowler HG (1979). Responses by a stingless bee to a subtropical environment. Rev. Biol. Trop. 27: 111-118

Herrera OM, Leopoldo PR, Kroll LB and Zuccari ML (1997). Agrupamento de estações climatológicas localizadas no Estado de São Paulo, utilizando-se análise multivariada. Eng. Agric. 16: 34-42.

Hilário SD and Imperatriz-Fonseca VL (2002). Seasonality influence on flight activity of Plebeia pugnax Moure (in litt.) (Hymenoptera, Apinae, Meliponini). Naturalia 27: 115-123.

Hilário SD, Imperatriz-Fonseca VL and Kleinert AMP (2000). Flight activity and colony strength in the stingless bee Melipona bicolor bicolor (Apidae, Meliponinae). Rev. Bras. Biol. 60: 299-306.

Hilário SD, Gimenes M and Imperatriz-Fonseca VL (2003). The influence of colony size in diel rhythms of flight activity of Melipona bicolor Lepeletier (Hymenoptera, Apidae, Meliponini). In: Apoidea Neotropica (Mello GAR and Alvesdos-Santos I, eds.). Universidade do Extremo Sul Catarinense, Criciúma, 191-197.

Hofstede FE and Sommeijer MJ (2006). Influence of environmental and colony factors on the initial commodity choice of foragers of the stingless bee Plebeia tobagoensis (Hymenoptera, Meliponini). Insectes Soc. 53: 258-264.

Inoue T, Salmah S, Abbas I and Yusuf E (1985). Foraging behavior of individual workers and foraging dynamics of colonies of three Sumatran stingless bees. Res. Popul. Ecol. 27: 373-392.

Iwama S and Melhem TS (1979). The pollen spectrum of the honey of Tetragonisca angustula angustula Latreille (Apidae, Meliponinae). Apidologie 10: 275-295.

Kajobe R and Echazarreta CM (2005). Temporal resource partitioning and climatological influences on colony flight and foraging of stingless bees (Apidae; Meliponini) in Ugandan tropical forests. Afr. J. Ecol. 43: 267-275.

Kerr WE, Stort AC and Montenegro MJ (1966). Importância de alguns fatores ambientais na determinação das castas do 
gênero Melipona. An. Acad. Bras. Cienc. 38: 149-168.

Lacerda LM, Zicchi R and Zucoloto FS (1991). Colony condition and bionomic alterations em Geotrigona inusitata (Apidae, Meliponinae). Acta Biol. Paranaense 20: 109-123.

Moretto G, Monteiro SG and Nogueira-Couto RH (1990). Estudo do fluxo de entrada e os tipos de pólen coletados em colmeias de Apis mellifera e Frieseomelitta varia. Rev. Cienc. Zootec. 5: 6-8.

Nagamitsu T and Inoue T (2002). Foraging activity and pollen diets of subterranean stingless bee colonies in response to general flowering in Sarawak, Malaysia. Apidologie 33: 303-314.

Nunes-Silva P (2007). A Organização e a Ritmicidade no Forrageamento e na Enxameação de Plebeia remota (Holmberg) (Hymenoptera, Apidae, Meliponini). Master's thesis, Instituto de Biociências, Universidade de S. Paulo, São Paulo.

Pierrot LM and Schlindwein C (2003). Variation in dialy flight activity and foraging patterns in colonies of uruçu Melipona scutellaris Latreille (Apidae, Meliponini). Rev. Bras. Zool. 20: 565-571.

Ramalho M (2004). Stingless bees and mass flowering trees in the canopy of Atlantic Forest: a tight relationship. Acta Bot. Bras. 18: 37-47.

Ramalho M, Kleinert-Giovannini A and Imperatriz-Fonseca VL (1989). Utilization of floral resources by species of Melipona (Apidae, Meliponinae): floral preferences. Apidologie 20: 185-195.

Ramalho M, Imperatriz-Fonseca VL and Giannini TC (1998). Within-colony size variation of foragers and pollen load capacity in the stingless bee Melipona quadrifasciata anthidioides Lepeletier (Apidae, Hymenoptera). Apidologie 29: $221-228$

Rensi C (2006). Fluxo Temporal de Pólen em Melipona marginata Lepeletier (Apidae, Meliponini) em Estações Distintas. Master's thesis, Instituto de Biociências, Universidade de S. Paulo, São Paulo.

Ribeiro MF, Imperatriz-Fonseca VL and Santos-Filho PS (2003). A Interrupção da Construção de Células de Cria e Postura em Plebeia remota (Holmberg) (Hymenoptera, Apidae, Meliponini). In: Apoidea Neotropica (Melo GAR and Alves-dos-Santos I, eds.). Universidade do Extremo Sul Catarinense, Criciúma, 177-188.

Roubik DW (1982). Seasonality in colony food storage, brood production and adult survivorship: studies of Melipona in tropical forest (Hymenoptera: Apidae). J. Kansas Entomol. Soc. 55: 789-800.

Roubik DW (1989). Ecology and Natural History of Tropical Bees. Cambridge University Press, Cambridge.

Roubik DW and Buchmann SL (1984). Nectar selection by Melipona and Apis mellifera (Hymenoptera: Apidae) and the ecology of nectar intake by bee colonies in a tropical forest. Oecologia 61: 1-10.

Roulston TH and Cane JH (2000). Pollen nutritional content and digestibility for animals. Plant Syst. Evol. 222: 187-209.

Sanches MM (2002). A Influência dos Fatores Climáticos na Atividade Externa de Plebeia (Friesella) schrottkyi (Apidae, Meliponini). Undergraduate Monograph, Faculdade de Ciências Biológicas, Exatas e Experimentais, Universidade Presbiteriana Mackenzie, São Paulo.

Souza BA, Carvalho CA and Alves RM (2006). Flight activity of Melipona asilvai Moure (Hymenoptera: Apidae). Braz. J. Biol. 66: 731-737.

Thorp RW (2000). The collection of pollen by bees. Plant Syst. Evol. 222: 211-223.

van Benthem FDJ, Imperatriz-Fonseca VL and Velthuis HHW (1995). Biology of the stingless bee Plebeia remota (Holmberg): observations and evolutionary implications. Insectes Soc. 42: 71-87.

Velthuis HHW, Vries HD and Imperatriz-Fonseca VL (2006). The polygyny of Melipona bicolor: scramble competition among queens. Apidologie 37: 222-239.

Wilms W and Wiechers B (1997). Floral resource partitioning between native Melipona bees and the introduced Africanized honey bee in the Brazilian Atlantic rain forest. Apidologie 28: 339-355. 